\title{
CRYOTHERAPY: A NEW TECHNIQUE TO OBTAIN GRAPEVINE PLANTS FREE OF VIRUSES ${ }^{1}$
}

\section{JEAN CARLOS BETTONI ${ }^{2}$, MURILO DALLA COSTA ${ }^{3}$, JOÃO PETERSON PEREIRA GARDIN ${ }^{3}$, AIKE ANNELIESE KRETZSCHMAR ${ }^{4}$, RANJITH PATHIRANA ${ }^{5}$}

\begin{abstract}
Through in vitro tissue culture techniques it is possible to propagate high quality nursery plants faster. Cryotherapy is a promising tool, based on in vitro culture techniques, for achieving in a short time, high frequency of regenerating plants free of viruses. The objective of this review is to present and analyze the results of research conducted in cryotherapy methods based on cryopreservation protocols for recovery of cultivars free of micro-organisms with potential agronomic interest. The main methods employed in cryotherapy are encapsulation-dehydration, vitrification, encapsulation-vitrification and droplet vitrification, which are based on the immersion of preconditioned shoot tips in liquid nitrogen, followed by their recovery in vitro on to culture media for regeneration of healthy plantlets. Improvements to cryotherapy protocols used for grapevine are still needed, since there are variations in response according to the genotype. The published research mostly relates to Vitis vinifera and the few studies applied to other species show that the protocols need to be improved. This specificity goes beyond species, with different responses among cultivars, limiting the broader application of the technology. On the other hand, traditional methods used for virus removal from infected plant materials also have limitations and therefore investment in research for the development and application of cryopreservation techniques is highly justified, considering its efficiency and low-cost, once the protocols are developed. High frequency of virus-free plants among regenerants within a short time frame is the most desirable aspect of cryotherapy. Therefore, these advantages make the technique a promising tool for institutions mandated to the development of high-health planting materials with high genetic and agronomic potential for viticulture.
\end{abstract}

Index Terms: Vitis, encapsulation-dehydration, encapsulation-vitrification, vitrification, droplet-vitrification, plant disease.

\section{CRIOTERAPIA: UMA NOVA TÉCNICA PARA OBTENÇÃO DE PLANTAS DE VIDEIRA LIVRES DE VIROSES}

\begin{abstract}
RESUMO - Por meio de técnicas de cultura de tecidos in vitro é possível propagar plantas matrizes de alta qualidade, mais rápido. A crioterapia é uma ferramenta promissora, baseada em técnicas de cultura in vitro para obtenção em curto espaço de tempo de alta frequência de plantas regenerantes livres de viroses. O objetivo desta revisão é apresentar e analisar os resultados de pesquisas realizadas em métodos de crioterapia, baseados em protocolos de criopreservação, para recuperação de cultivares de videiras livres de microorganismos e com potencial de interesse agronômico. Os principais métodos utilizados para crioterapia são encapsulamento-desidratação, encapsulamento-vitrificação, vitrificação e vitrificação de gota, os quais se fundamentam na imersão de ápices meristemáticos pré-condicionados em nitrogênio líquido, seguido por sua recuperação in vitro em meios de cultura para regeneração de plântulas saudáveis. Melhorias para protocolos de crioterapia empregados para a videira ainda são necessários, uma vez que existem variações na resposta de acordo com o genótipo. As investigações publicadas na sua grande maioria estão relacionadas a cultivares de Vitis vinifera e os poucos estudos aplicados a outras espécies mostram que os protocolos precisam ser melhorados. Essa especificidade, que vai além da espécie, com respostas diferenciadas entre cultivares, por enquanto limita a aplicação mais ampla da tecnologia. Por outro lado, os métodos tradicionais utilizados para eliminação de viroses a partir de materiais de plantas infectadas também possuem limitações e, portanto, investimentos em pesquisas para o desenvolvimento e aplicação de técnicas de criopreservação são altamente justificáveis, considerando a sua eficiência e o baixo custo, uma vez que os protocolos são desenvolvidos. Essas limitações deverão ser superadas. Alta frequência de plantas livres de vírus entre os regenerantes dentro de um curto espaço de tempo é o aspecto mais desejável da crioterapia. Portanto, essas vantagens fazem da técnica de crioterapia uma ferramenta promissora para instituições especializadas para o desenvolvimento de materiais de plantio de alta qualidade fitossanitária com alto potencial genético e agronômico para a viticultura.
\end{abstract}

Termos para indexação: Vitis, encapsulamento-desidratação, encapsulamento-vitrificação, vitrificação, doenças de plantas.

\footnotetext{
'(Trabalho 187-15). Recebido em: 29-07-2015. Aceito para publicação em: 08-10-2015.

${ }^{2}$ Eng. Agr., Esp. Viticultura e Enologia, Doutorando em Produção Vegetal- UDESC -CAV, , Lages (SC), E-ail: jcbettoni@gmail.com; ${ }^{3}$ Engs. Agrs., Drs. Pesquisadores da EPAGRI. E-mails: murilodc@epagri.sc.gov.br; joaogardin@epagri.sc.gov.br

${ }^{4}$ Eng. Agr., Dra. - UDESC-CAV, Lages-SC. E-mail: a2aak@cav.udesc.br

${ }^{5}$ Eng. Agr., Dr. Plant and Food Research, Department of Breeding and Genomics, Auckland, New Zealand. E-mail: ranjith.pathirana@ plantandfood.co.nz
} 


\section{INTRODUCTION}

In Brazil, grapevine occupies an area of 81.286 hectares, and $71.15 \%$ of this area is in the temperate zone in Rio Grande do Sul, Santa Catarina and Paraná States (SIDRA, 2013). Although there is a favorable commercial scenario, area planted with grapevine and the harvest in the south of Brazil have been declining, it is observed that new vineyards face low productivity and poor quality of grapes due to several complex issues. In relation to plant health, one of the most important obstacles is the infection of vines with viruses, resulting in vine decline and death (BETTONI et al., 2015; GARRIDO et al., 2004).

Viruses have become a barrier to productive development of a profitable viticulture. Infected plants show growth reduction, low productivity and poor quality of grapes which can decline and die in few years (WANG et al., 2003a; FAJARDO et al., 2007). A worrying factor is that the viruses are disseminated by the use of infected propagating material contributing to the spread of virus in new areas. According to Shatnawi et al. (2011), some species show symptoms such as leaf yellowing, bright yellow stripes near to the nerves and nerve bifurcation. In contrast, some American and hybrid cultivars do not show typical virus infection symptoms, remaining latent, making the diagnosis difficult and misleading, so further facilitating virus dissemination.

The acquisition of plant material with origin and guarantee of high-health status is important for the success in vineyard establishment and management. In practice, it is often difficult to maintain such standards, and high-health planting material is not available in the market. Therefore, it is necessary to identify and implement functional and robust methods in order to eliminate microorganisms, using efficient protocols, able to generate highhealth materials for promoting efficient vineyard practices (PATHIRANA et al., 2012; 2013). It is necessary to follow this with stringent regulatory measures for clonal grapevine nurseries, in relation to maintenance, propagation and commercialization of plant materials. Considering the limitation of traditional methods in obtaining mother plants free of viruses, the development of new and more efficient technologies is important, with practical and efficient protocols, to produce healthy plants (WANG et al., 2009). In vitro techniques can have a positive impact in overcoming the problems associated with production of high-health nursery material in order to optimize, stabilize and maximize the grape industry.

Cryotherapy is a biotechnological method used to eliminate pathogens from infected clonal plant materials and it is based on cryopreservation using vitrification techniques, in which the biological material is exposed to liquid nitrogen (LN) at -196 ${ }^{\circ} \mathrm{C}$ for a period. Under these conditions, infected vacuolated and differentiated cells are eliminated by the ultra-low temperature effect, leaving only highly cytoplasmic meristematic cells. Cryotherapy has been used successfully in eradicating virus infection from several species with economic importance as plum, banana, strawberry, potato and garlic, besides grapevine (WANG and VALKONEN, 2009a; VIEIRA et al., 2015). High efficiency of cryotherapy in several species, combined with the low operational costs and rapid recovery of plant material without virus infection at a high frequency, have made this method a promising tool for institutions aiming at the recuperation of crops with agronomic potential. Being a new method, there are still few studies in using cryotherapy in comparison with the traditional methods in eliminating viruses, and results on agronomic evaluation of plants that were subjected to cryotherapy are still not available in literature. Despite the benefits and positive results of cryotherapy technique, challenges still remain due to variable response of genotypes within and between species, restricting the applicability of cryotherapy (WANG et al., 2014; FENG et al., 2013). Hence, the next stage of progress in this field will see the development of robust protocols applicable across genotypes, in each studied species, in order to maximize the generation of plants without viral particles. Further evaluation of genetic stability and agronomic behavior of treated plant material is another aspect that will be addressed in cryotherapy research in the coming years.

Therefore, the objective of this review is to present results from research performed with cryotherapy methods based on protocols of cryopreservation, in order to recover in vitro grapevine plants without viruses. 


\section{METHODS OF VIRUS ERRADICATION FROM INFECTED PLANT MATERIAL}

Traditional methods used to obtain plant material without pathogens include meristem culture and heat therapy followed by meristem culture (DÍAS-BARRITA et al., 2007; MALIOGKA et al., 2009).

There are successful scientific reports of techniques in several species; however, in functional terms, methodological difficulties have hampered the extensive use of these biotechnological tools (WANG et al., 2014). In meristem culture, which has been used for decades, the elimination capacity of viral particles is associated with the dimension of the excised tissue. For majority of species, the recommended size is extremely small, from 0.1 to $0.3 \mathrm{~mm}$ (TORRES et al., 1998). Besides the mechanical problems with meristem removal, the low regeneration capacity and, mainly, the failure to guarantee the removal of viral particles are the bottlenecks (FACCIOLI and MARANI, 1998; DÍASBARRITA et al., 2007). Heat therapy application with meristem culture is an expensive process, demanding proper equipment; the treatment period is dependent on the type of virus and not all viruses are eliminated by the technique and many host plants are heat sensitive (BHOJWANI and DANTU, 2013).

Other methods are noted as alternative ones for the elimination of viruses, among them are somatic embryogenesis and chemotherapy. Somatic embryogenesis, besides a time-consuming method, is difficult to be executed and, at the end, it can cause somaclonal variation in regenerated plants. However, there are reports of successful elimination of grapevine viruses using somatic embryogenesis. Gambino et al. (2009) related the efficiency of somatic embryogenesis for eradicating the virus responsible for grapevine degeneration (Grapevine Fan Leaf Virus) for three Vitis vinifera cultivars (Cari, Provinè and Roussan). Chemotherapy protocols were applied successfully to remove the virus responsible for grapevine leaf-roll disease (GLRaV-1 and 3) (PANATTONI et al., 2011), but there are also reports demonstrating high phyto-toxicity induced by antiviral compounds. Moreover, variable responses have been observed among different cultivars and there is no research proving that antiviral compounds do not induce mutagenic alteration. In general, all the above mentioned techniques have their disadvantages and each needs to be optimized (SKIADA et al., 2013).

\section{CRYOTHERAPY}

Cryotherapy is a relatively new method used to eliminate pathogens from infected plant tissue based on cryopreservation techniques. In this method, the biological material is exposed to $\mathrm{LN}$ at $-196{ }^{\circ} \mathrm{C}$ for a short period, normally 1 hour, (FENG et al., 2013) and under those conditions, infected cells in the vascular region and vacuolated, more differentiated cells of the apical dome are eliminated by the ultralow temperature due to ice crystallisation, leaving only highly cytoplasmic cells in the meristematic region (WANG and VALKONEN, 2008b). Thus, the technique is based on the physico-anatomical differences among tissues, because meristematic cells are small, with smaller vacuoles and greater nuclear-cytoplasm ratio than cells which are further from the meristematic region (Figure 1) (WANG et al., 2009; WANG and VALKONEN, 2009a). Since meristematic cells are smaller and proliferating fast, away from the vasculature, it is suggested that virus may not reach that region (WANG and VALKONEN, 2009a). Cryotherapy has been used successfully in eradicating virus infections in several species with economic importance such as Prunus (BRISON et al., 1997), Musa spp. (HELLIOT et al., 2002), Vitis vinifera (WANG et al., 2003a; BAYATI et al., 2011; PATHIRANA et al., 2015), Fragaria ananassa (CAI et al., 2008), Solanum tuberosum (WANG et al., 2006; BAI et al., 2010; 2012; YI et al. 2014), Rubus idaeus (WANG and VALKONEN 2009b; WANG et al., 2008), Ipomea batatas (WANG and VALKONEN, 2008a), Dioscorea opposite (HEE et al., 2013) and Allium sativum (VIEIRA et al., 2015) (Table 1).

Considering the results from about a decade of research, cryotherapy can be considered as a fast developing method that helps and/or replaces traditional methods in eradicating microorganisms from infected plant tissue (WANG and WALKONEN, 2009). There are a number of advantages in cryotherapy technique in relation to traditional methods for pathogen eradication (WANG et al., 2003a); ability to treat a large number of samples quickly and simultaneously (BHOJWANI and DANTU, 2013); low cost and high frequency of plants free from viruses after recovery (FENG et al., 2013; WANG et al., 2006; WANG et al., 2003a). After the protocol establishment for the genotype in question, the technique is easy and does not require special equipment, only basic equipment available in a tissue culture laboratory (WANG et al., 2009).

The greatest challenge to the wider application of cryotherapy technique is the differentiated 
response that genotypes of the same species can show under cryo-treatment, which still limits the applicability of cryotherapy (WANG et al., 2014; FENG et al., 2011; 2013; WANG and WALKONEN, 2009). Several protocols with different cryotherapy methods have been reported and results differ between laboratories, with varying levels of survival and regeneration (BENELLI et al., 2013; GRIBAUDO et al., 2012; BENSON, 2008; WANG et al., 2003a; MATSUMOTO and SAKAI, 2003).

Intracellular water content is a critical factor for the efficiency of cryotherapy protocols. It is important to achieve proper dehydration of plant material, reducing harmful damage to tissues (ENGELMANN, 2004). Wang et al. (2000), working with Vitis sp., reached higher indexes of survival when tissue water content was near $16 \%$ at the time of cryopreservation; in contrast, higher or lower water content in the tissue decreased the survival. Excessive dehydration causes negative effects on survival rate and, likewise, water in excess in the tissue causes irreversible damage because water crystallization inside the cell causes rupture of cell membrane system, cell collapse and death (VIEIRA et al., 2015; WANG et al., 2009). So, before the exposure of plant tissue to $\mathrm{LN}$, part of the intracellular water is removed by the addition of plant vitrification solution 2 (PVS2) (SAKAI et al., 1990; MATSUMOTO and SAKAI, 2003; GRIBAUDO et al., 2012), or they are physically dehydrated using silica gel or by exposing to the air flow of the laminar hood (WANG et al., 2000).

There are still fewer studies on the use of cryotherapy in comparison with the traditional methods for eliminating viruses, and results on agronomic evaluation of plants that have undergone cryotherapy are yet to be published (WANG et al., 2014). Several different techniques have been applied for cryotherapy of Vitis spp. These include vitrification (MARKOVIC et al., 2013; GANINO et al., 2012; MATSUMOTO and SAKAI, 2003; WANG et al., 2003a), encapsulationdehydration (MARKOVIC et al., 2013; BAYATI et al., 2011; WANG et al., 2003a; WANG et al., 2000), encapsulation-vitrification (GRIBAUDO et al., 2012) and droplet vitrification (PATHIRANA et al. 2015).

\section{CRYOTHERAPY BY VITRIFICATION}

Vitrification protocols are based on dehydrating material in cryoprotective glycerol based solutions such as PVS2 and PVS3 (SAKAI and ENGELMANN, 2007). Once sufficiently dehydrated, the sparsely distributed water molecules in plant tissues are unable to come together to form ice crystals during rapid freezing. Therefore they undergo a transition from liquid to a vitreous state, when the material is exposed to LN (FAHY et al., 1984). This phenomenon, known as vitrification, is facilitated by ultra-fast cooling rates achieved by direct dipping of plant material in LN. PVS2, the most efficient vitrification solution developed so far, is composed of $30 \%(\mathrm{w} / \mathrm{v})$ glycerol, $15 \%(\mathrm{w} / \mathrm{v})$ ethylene glycol, $15 \%(\mathrm{w} / \mathrm{v})$ dimethyl sulfoxide (DMSO) in Murashige and Skoog (1962) medium (MS) with $0.4 \mathrm{M}$ sucrose (MATSUMOTO and SAKAI, 2003; WANG et al., 2003a). PVS3, which has been successfully used in a limited number of species such as asparagus is composed of $50 \%$ $(\mathrm{w} / \mathrm{v})$ glycerol and $50 \%(\mathrm{w} / \mathrm{v})$ sucrose in water (NISHIZAWA et al., 1993). When comparing the effect of PVS2 and PVS3 on Vitis vinifera dehydration, Markovic et al. (2013) observed that, 40 minutes exposure followed by LN treatment for one hour resulted in no plant recovery using PVS3, whereas $40 \%$ of survival was achieved with PVS2 dehydration. Vitrification protocols involve the following stages: excision of meristematic tissue (apical or axillary buds) from in vitro propagated material; pre-culture in sucrose-enriched media ( 0.3 $\mathrm{M}$, or increasingly higher sucrose concentrations up to $1 \mathrm{M}$ ); osmoprotection in liquid culture medium enriched with glycerol and sucrose; dehydration with vitrification solution (PVS2 or PVS3); instant freezing in $\mathrm{LN}$ at $-196{ }^{\circ} \mathrm{C}$; recovery on to warm (in a water bath heated to $38-40^{\circ} \mathrm{C}$ ) recovery solution (liquid culture medium enriched with sucrose) followed by transfer to high sucrose solid media; and regeneration on culture medium (MATSUMOTO and SAKAI, 2003; MIAJA et al., 2004; SAKAI and ANGELMANN, 2007).

Variations in vitrification protocols for Vitis sp. comprise of sucrose concentrations used in osmoprotection and rinsing stages, exposure time to cryo-protectants and regeneration medium (MARKOVIC et al., 2014; GANINO et al., 2012; WANG et al., 2003a; MATSUMOTO and SAKAI, 2003; NISHIZAWA et al., 1992). In any vitrification method, procedures such as pre-culture, osmoprotection, exposure time to cryo-protectants and careful handling during and after LN treatment 
are essential for survival and regeneration of the tissues containing meristematic cells (SAKAI and ENGELMANN, 2007).

Using $V$. vinifera $\mathrm{cv}$. Cabernet Sauvignon, Matsumoto and Sakai (2003) observed that preculture of shoot tips in $0.3 \mathrm{M}$ sucrose concentration for 3 days was optimal, with $65.5 \%$ recovery after freezing. On the other hand, Wang et al. (2003a) working with another cultivar from the same species, reached $50 \%$ of regeneration after cryopreservation when shoot tips were pre-cultured with $0.75 \mathrm{M}$ sucrose. Different responses from genotypes for cryotherapy techniques make it difficult to develop generalized protocols for Vitis, so demanding adjustments to protocols for different cultivars (WANG et al., 2014).

Optimising the time of exposure of explants to cryoprotective solutions is needed in order to establish vitrification protocols. Excessive exposure can cause injuries by chemical toxicity and death of meristem cells (SAKAI and ENGELMANN, 2007; SAKAI, 1995). In Kober 5BB rootstock (Vitis berlandieri x Vitis riparia), GANINO et al. (2012) observed the effect of PVS2 toxicity in grapevine shoot tips: without both cryoprotective treatment and freezing, $94 \%$ of the plants regenerated; after 30 minutes of exposure, $57 \%$ of the plants regenerated; after 60 minutes, the regeneration dropped to $14 \%$; and after 90 minutes there was no regeneration even without subjecting tissues to freezing. Likewise, MARKOVIC et al. (2013) noted a decrease in survival and regeneration of grapevines with the increase of dehydration period by PVS2: survival decreased from $70 \%$ in 25 minutes treatment to $30 \%$ after 75 minutes of treatment. For Vitis, the best results in dehydration using PVS2 have been achieved when the process was performed in two stages, with initial exposure of explant material for 30 minutes to $1 / 2$ PVS2 (15\% glycerol, $7.5 \%$ ethylene glycol, $7.5 \%$ DMSO and $0.4 \mathrm{M}$ of sucrose) followed by a treatment for 50 minutes in PVS2. Wang et al. (2003a), Matsumoto and Sakai (2003), using dehydration by PVS2 in two stages reached $50 \%$ and $82.5 \%$ of Vitis regenerated plants, respectively. Exposure time to PVS2 varies among species; in general, tissues smaller than $0.5 \mathrm{~mm}$ are more sensitive to treatment with PVS2, but those tissues exceeding $3 \mathrm{~mm}$ require greater dehydration time (SAKAI and ENGELMANN, 2007).

After dehydration, plant material is placed in cryo-tubes with cryo-protectors and subjected to NL freezing for 1 hour; after, it is thawed in recovery solution at $40^{\circ} \mathrm{C}$ for 3 minutes by keeping inside a pre-heated water bath (WANG et al., 2003a). Rinsing and caution in handling plant material after defrosting are essential to cryotherapy success (SAKAI and ENGELMANN, 2007).

Success in vitrification method for eliminating viruses from grapevine was demonstrated by Wang et al. (2003a) who noted $97 \%$ of regenerated plants without GVA (Grapevinevirus A) against only $12 \%$ after meristem culture. Recently, Pathirana et al. (2015) demonstrated the removal of three Closteroviridae viruses causing leafroll disease in grapevine, using vitrification-based cryotherapy of apical and axillary buds of infected clones.

\section{CRYOTHERAPY BY ENCAPSULATION-DEHYDRATION}

Cryotherapy by the method of encapsulationdehydration is based on techniques proposed for synthetic seed production (BENELLI et al., 2013). The protocol involves the following stages: excision of in vitro propagating material; encapsulation; precultivation under cumulative sucrose concentrations; dehydration; freezing at $-196{ }^{\circ} \mathrm{C}$; defrosting in water bath at $40^{\circ} \mathrm{C}$; and culture on regeneration medium.

After excision of in vitro propagating material, the method consists in the formation of a artificial endosperm around the tissue composed by a gelling agent ( $3 \%$ sodium alginate) which cures when contacting calcium chloride solution and produces small pellets (BAYATI et al., 2011; GONZÁLEZ-BENITO et al., 2004). In sequence, they are pre-cultivated in solutions with increasing sucrose concentrations $(0.25,0.50,0.75$ and 1.0 $\mathrm{M})$, during four days, a stage per day (MARKOVIC et al., 2013; BAYATI et al., 2011; WANG et al., 2000; WANG et al., 2003a). Pre-cultivation allows encapsulated propagating materials become resistant to dehydration and freezing; in turn, the gradual increase of sucrose concentration prevents harmful effects of the plant exposure to high sucrose concentrations (PLESSIS et al., 1991). Encapsulation protects the tissue from high sucrose concentrations, preventing injury in cell tissues (ENGELMANN, 2011), which could otherwise be harmful or fatal for non-encapsulated propagating material (MATSUMOTO and SAKAI, 2003).

After pre-cultivation, encapsulated tissue can be dehydrated under air flow in laminar air flow cabinet (WANG et al., 2003a) or in containers with silica-gel (MARKOVIC et al., 2013). Comparing both techniques on the survival of LN 33 grapevine hybrid (Courderc 1613 x Sultana), Wang et al. (2000) showed that results were not dependent on dehydration method but on dehydration time of 
each method and the original water content in the propagating material including the beads. The best survival rate achieved was around $60 \%$ when beads were dehydrated for 7 hours on air flow and 4.5 hours in silica-gel, with a final water content of about $16 \%$. For Vitis vinifera, Portan cultivar, around $10 \%$ of the plants regenerated at a range of bead moisture contents, from $16.2 \%$ to $22.3 \%$ (MARKOVIC et al., 2013). After 12 hours of dehydration under air flow and NL freezing, 59\% of encapsulated shoot tips of $V$. vinifera, Black cultivar survived (BAYATI et al., 2011). For cv. Superior ( $V$. vinifera), dehydration periods of more than 6 hours decreased survival rate of encapsulated shoot tips (WANG et al., 2000). Results from aforementioned research indicate that the dehydration time of encapsulated tissue to reach proper water content is variable and cultivars from the same species show different survival and regeneration rates. Thus, in order to achieve higher survival rates from a specific cultivar it is important to investigate, initially, the sole effect of dehydration before attempting cryotherapy.

After dehydration, encapsulated tissue is transferred to sterile cryo-tubes for treatment in LN for 1 hour, and afterwards, they are thawed in recovery solution maintained on a water bath set at $40^{\circ} \mathrm{C}$ for 3 minutes and then transferred to regeneration culture medium (BAYATI et al., 2011; WANG et al., 2003a; WANG et al., 2000).

Successful attempts on encapsulationdehydration method to eradicate viruses from infected grapevine have been reported. Bayati et al. (2011) and Wang et al. (2003a) have registered frequencies of 42.2 and $97 \%$ of plants free from GVA, with 59 and $62 \%$ of survival after cryotherapy, respectively.

\section{CRYOTHERAPY BY ENCAPSULATION-VITRIFICATION}

Encapsulation-vitrification protocols are based upon combinations of encapsulationdehydration and vitrification procedures (BENELLI et al., 2013; ENGELMANN, 2011). For this method, shoot tips from in vitro cultures are excised and encapsulated in alginate beads as already described. The encapsulated beads are then pre-cultured in solutions with increasing sucrose concentrations, followed by osmoprotection in loading solution followed by dehydration with vitrification solution, freezing at $-196{ }^{\circ} \mathrm{C}$, defrosting in water bath at $40{ }^{\circ} \mathrm{C}$, rinsing in recovery solution and culture in regeneration media. In literature, there are few studies relating the use of encapsulation-vitrification method to eradicate viruses in crops. Gribaudo et al. (2012) investigated the efficiency of this method in $\mathrm{cv}$. Nebbiolo cultivar ( $V$. vinifera) infected with GVA and GLRaV-3 and, after cryotherapy, the healthy vegetative material was regenerated.

The convenience of vitrification technique allows that shoot tip explants could be subjected to cryotherapy for a short time; however, it requires extra care during handling when compared with encapsulation-dehydration method, in which the procedures are done with encapsulated shoot apices. On the other hand, the encapsulation-dehydration method demands more time to prepare material for freezing, especially in dehydration phase. So, encapsulation-vitrification method benefits from both encapsulation-dehydration and vitrification advantages (SAKAI and ENGELMANN, 2007).

\section{CRYOTHERAPY BY DROPLET VITRIFICATION}

The droplet vitrification method was first applied by Schafermenuhr et al. (1994) for cryopreserving potato meristems. It combines the application of highly concentrated vitrification solutions with ultra-fast freezing and thawing rates, which are critical for its successful results (PANIS et al. 2005).

This method involves the treatment of samples with cryoprotectants, which mainly includes exposure to the loading solution, followed by dehydrating in PVS2 vitrifying solution. The samples are then placed on an aluminum foil strip mounted with a droplet of vitrifying solution and immersed in LN for rapid cooling. During rewarming, the removal of cryoprotectant is achieved using unloading solution, and then transferred to recovery and regeneration media (BENELLI et al. 2013). It is vital that the samples are sufficiently dehydrated by the vitrification solution in order to vitrify while rapid cooling in LN. Thus the key for successful droplet vitrification is to quantify and optimize the dehydration tolerance of samples in vitrifying solution. Tolerance to vitrification solution is achieved by optimizing the preconditioning and loading treatments along with the standardization of concentration, time of exposure and temperature of the vitrification solution. Similar to other methods, the warming and recovery steps are also crucial for its success (GONZALEZ-ARNAO et al. 2014; SAKAI and ENGELMANN 2007). Droplet vitrification achieves fastest rates of cooling thanks to the high 
thermal conductivity of aluminum, and researchers believe that this method will become a generic method applicable to many species in future (PANIS et al., 2009; 2011).

Droplet vitrification method has been successfully applied to removing three Closteroviridae viruses from infected grapevine clones (PATHIRANA et al. 2015). They used 'Chardonnay' and 'Lakemont Seedless' infected with Grapevine leafroll associated virus-3 (GLRaV-3, an Ampelovirus), 'Pinot gris' and 'Sauvignon Blanc 316' infected with Grapevine leafroll associated virus-2 (a Closterovirus), and another clone of 'Sauvignon Blanc' infected with both Grapevine leafroll associated virus-1 (an Ampelovirus) and GLRaV-3. Plants regenerated after cryo-treatment tested negative for all three viruses, whereas untreated control plants tested positive.

\section{GENERAL CONDITIONS FOR CRYOTHERAPY METHODS}

Regardless of the cryotherapy method or protocol, it is important that conditions after cryotherapy be favorable for survival and regeneration of the cryopreserved material. Optimising the concentration of growth regulators (WANG et al., 2000) or composition of culture media (PENNYCOOKE and TOWILL, 2001) is essential for good regeneration of cryo-preserved buds. Growth regulators play important roles in regeneration medium (WANG et al., 2003b) and they can meet specific requirements in the recovery of cryo-preserved materials (BHOJWANI and RAZDAN, 1996). Markovic et al. (2014) highlighted that growth regulators such as trans-zeatin riboside (ZR) and benzyl amino purine (BAP) act in the same way in recovering grapevine cryo-preserved shoot tips and, even in small concentrations, they are essential to regenerate explant materials. The effects of culture medium supplemented with different concentrations of BAP and naphthaleneacetic acid (NAA) on the development of cryo-preserved grape buds were evaluated by Wang et al. (2000). Fastest shoot elongation without any callus formation was obtained when cryopreserved shoot tips were cultured on the post-culture medium composed of half-strength MS medium supplemented with 1 $\mathrm{mg} / \mathrm{L} \mathrm{BA}$ and $0.1 \mathrm{mg} / \mathrm{L}$ NAA. However, a further increase in BAP or NAA concentration, when used in combination, resulted in callus formation. This is undesirable for cryotherapy because it can cause somaclonal variation (WANG et al., 2003b). Optimum concentration of growth regulators in regeneration medium for cryo-preserved materials has varied among cryogenic methods (WANG et al., 2003b) and among cultivars (WANG et al., 2000). Therefore, investigative research needs to be performed on selected genotypes in each species, in combination with vitrification, encapsulationdehydration, encapsulation-vitrification and droplet vitrification methods, in order to establish efficient protocols which can result in high survival rates with high frequency of viruses eradication. 
TABLE 1 - Efficiency of cryotherapy methods for eradication of viruses in plant species.

\begin{tabular}{|c|c|c|c|}
\hline Pathogen & Plant species & $\begin{array}{c}\text { Cryotherapy } \\
\text { method }\end{array}$ & References \\
\hline Plum pox virus & Prunus & VI & Brison et al. (1997) \\
\hline Banana streak virus & Musa & VI & Helliot et al. (2002) \\
\hline Cucumber mosaic virus & Musa & VI & Helliot et al. (2002) \\
\hline Grapevine virus $A$ & Vitis vinifera & EN-DE; VI & Wang et al. (2003) \\
\hline Potato virus $Y$ & Solanum tuberosun & $n$ EN-DE; VI; DR-VI & Wang et al. (2006) \\
\hline Potato leafroll virus & Solanum tuberosun & $n$ EN-DE; VI; DR-VI & Wang et al. (2006) \\
\hline Strawberry mild yellow-edge virus & Fragaria ananassa & VI & Cai et al. (2008) \\
\hline Sweet potato feathery mottle virus & Ipomoea batatas & EN-VI & Wang and Valkonen (2008a) \\
\hline Sweet potato chlorotic stunt virus & Ipomoea batatas & EN-VI & Wang and Valkonen (2008a) \\
\hline Sweet potato little leaf phytoplasma & Ipomoea batatas & EN-VI & Wang and Valkonen (2008a) \\
\hline Raspberry bushy dwarf virus* & Rubus idaeus & EN-VI & Wang et al. (2008b) \\
\hline Raspberry bushy dwarf virus & Rubus idaeus & EN-VI & Wang and Valkonen (2009b) \\
\hline Grapevine virus $A$ & Vitis vinifera & EN-DE & Bayati et al. (2011) \\
\hline Potato Virus $X$ & Solanum tuberosun & $n \mathrm{DR}-\mathrm{VI}$ & Bai et al. $(2010 ; 2012)$ \\
\hline Potato Spindle Tuber Viroid & Solanum tuberosun & $n \mathrm{DR}-\mathrm{VI}$ & Bai et al. (2012) \\
\hline Yam mosaic virus & Dioscorea oppositc & $a$ EN-DE & Hee et al. (2013) \\
\hline Potato leafroll virus & Solanum tuberosun & $n$ DR-VI; EN-VI & Yi et al. (2014) \\
\hline Potato virus $Y$ & Solanum tuberosun & $n$ DR-VI; EN-VI & Yi et al. (2014) \\
\hline Onion Yellow Dwarf Virus & Allium sativum L. & VI & Vieira et al (2015) \\
\hline Leek Yellow Strip Virus & Allium sativum L. & VI & Vieira et al (2015) \\
\hline Garlic Common Latent Virus & Allium sativum L. & VI & Vieira et al (2015) \\
\hline Grapevine associated virus 1 & Vitis vinifera & DR-VI & Pathirana et al. 2013; 2015 \\
\hline Grapevine associated virus 2 & Vitis vinifera & DR-VI & Pathirana et al. 2013; 2015 \\
\hline Grapevine associated virus 3 & Vitis vinifera & DR-VI & Pathirana et al. 2013; 2015 \\
\hline
\end{tabular}

VI: Vitrification; EN-DE: Encapsulation-Dehydration; EN-VI: Encapsulation-Vitrification; DR-VI: Droplet-Vitrification.

* Thermotherapy followed by cryotherapy by Encapsulation-Vitrification 


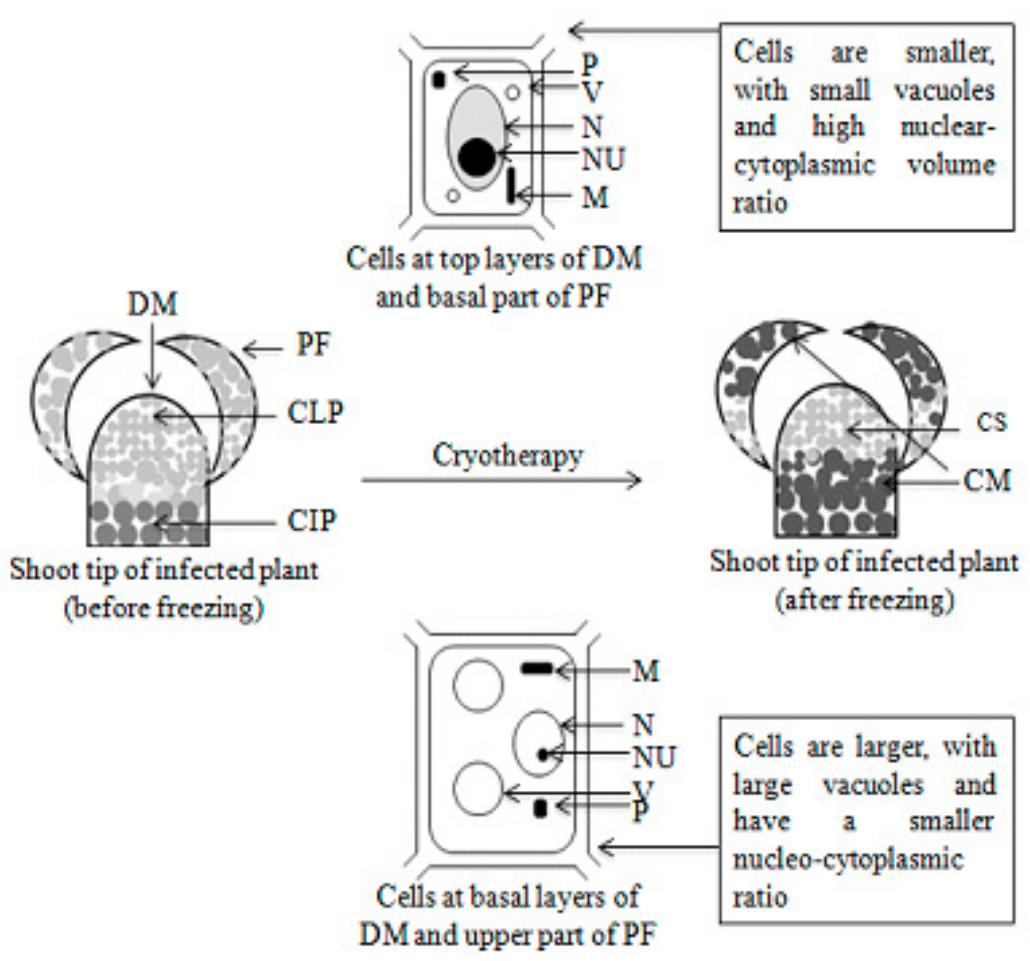

FIGURE 1 - Layout of physical-anatomic differences in cells near and far from the meristematic domein the apical zone. Cells in upper meristematic dome and basal part of leaf primordia are smaller, with small vacuoles and high nuclear-cytoplasm ratio, while cells in the lower part of meristematic dome and upper part of leaf primordia are larger, with bigger vacuoles and low nuclear-cytoplasm ratio and are more prone to injuries after cryotherapy. DM, meristematic dome; PF, leaf primordia; CLP, cells without pathogen; CIP, cells infected by pathogen; CS, surviving cell; CM, dead cells; M, mitochondria; V, vacuole; NU, nucleus; N, nucleolus; P, proplastid. Source: Wang and Valkonen (2009a).

\section{CONCLUSION}

Improvements to cryotherapy protocols applied for grapevine are still needed. Most of the published investigations are related to Vitis vinifera and studies applied to cultivars from other genetic backgrounds have shown that the same protocols are not suitable. For now, that specificity with different responses among cultivars, beyond the species, limits the wide applicability of cryotherapy. Conversely, traditional methods used to eliminate viruses also have limitations and, with the development and investment in research on cryo-preservation techniques, those barriers could be overcome. Some features of cryotherapy make it very attractive for institutions aiming at the development of high-health nursery material with agronomic potential. These features include its applicability across many species of plants, low running cost and the development of plants free from virus quickly and at a high frequency.

\section{ACKNOWLEDGEMENT}

To CAPES (Coordenação de Aperfeiçoamento de Pessoal de Nível Superior: a government agency linked to the Brazilian Ministry of Education in charge of promoting high standards for post-graduate courses in Brazil) for scholarship to the first author. RP wishes to thank The New Zealand Institute for Plant \& Food Research Limited CORE funding: 1972 - 'Breeding Technology Development' for project CORE CRYOTHERAPY P/150444/15,for financial support.

To EPAGRI (Empresa de Pesquisa Agropecuária e Extensão Rural de Santa Catarina) and FAPESC (Fundação de Amparo à Pesquisa do Estado de Santa Catarina) for financial support. 


\section{REFERENCES}

BAI, J.M.; CHEN, X.L.; LU, X.X.; GUO, H.C.; XI, X.; ZHANG, Z.E. Can cryopreservation eliminate the potato virus $\mathrm{X}(\mathrm{PVX})$ and potato spindle tuber viroid (PSTVd)? Bioscience Methods, Saskatoon, v.3, p.34-40, 2012.

BAI, J.M.; CHEN, X.L.; LU, X.X.; GUO, H.C.; XI. X.; ZHANG, Z.E. Elimination of Potato virus $\mathrm{X}$ Potato spindle tuber viroid by cryopreservation. Molecular Plant Breeding, Wallingford, v.8, p.605$611,2010$.

BAYATI, S.; SHAMS-BAKHSH, M; MOIENI, A. Elimination of grapevine virus A (GVA) cryotherapy and electrotherapy. Journal of Agricultural Science and Technology, Libertyville, v.13, p.443-450, 2011.

BENELLI, C.; DE CARLO, A.; ENGELMANN, F. Recent advances in the cryopreservation of shootderived germplasm of economically important fruit trees of Actinidia, Diospyros, Mallus, Olea, Prunus, Pyrus and Vitis. Biotechnology Advances, New York, v.31, p.175-185, 2013.

BENSON, E. E. Cryopreservation of phytodiversity: a critical appraisal of theory \& practice. Critical Reviews in Plant Sciences, Boca Raton, v.27, p.141-219, 2008.

BETTONI, J.C.; COSTA, M.D.; GARDIN, J.P.; KRETZCHMAR, A.; SOUZA, J. A.. In vitro Propagation of Grapevine Cultivars with Potential for South of Brazil. American Journal of Plant Sciences, Irvine, v.6, p.1806-1815, 2015.

BHOJWANI, S.S.; DANTU, P.K. Production of Virus-Free Plants. In: BHOJWANI, S.S.; DANTO, P.K. Plant Tissue Culture: an introductory text. New Delhi: Springer India, 2013. cap.6, p.227-243.

BHOJWANI, S.S.; RAZDAN M.K. Plant tissue culture: theory and practice. Studies in Plant Science. Amsterdam: Elsevier Science, 1996. 767 p.

BRISON, M.; BOUCAUD, M.T.; PIERRONNET, A.; DOSBA, F. Effect of cryopreservation on the sanitary state of a cv. Prunus rootstock experimentally contaminated with plum pox potyvirus. Plant Science, Shannon, v.123, p.189-196, 1997.
CAI, B.H.; ZHANG, J.Y.; QU, S.C.; GAO, Z.H.; QUIAO, Y.S.; ZHANG, Z.; ZHU, F. Preliminary study on the elimination of Strawberry mild yellowedge virus from in vitro shoot tips of strawberry cv. Meihou by vitrification cryopreservation. Journal Fruit Science, Beijing, v.25, p.872-876, 2008.

DÍAS-BARRITA, A.J.; NORTON, M.; MARTINEZPENICHE, R.A.; UCHANSKI, M.; MULWA, R.; SKIRVIN, R. M. The use of Thermotherapy and in vitro Meristem Culture to Produce Virus-Free 'Chancellor' Grapevines. International Journal of Fruit Science, New York, v.7, p.15-25, 2007.

ENGELMANN, F. Plant cryopreservation: progress and prospects. In Vitro Cellular Development and Biology - Plant, Columbia, v.40, p.427-433, 2004.

ENGELMANN, F. Use of biotechnologies for the conservation of plant biodiversity. In vitro Cellular \& Development Biology-Plant, Columbia, v.47, p.5-16, 2011.

FACCIOLI, G.; MARANI, F. Virus elimination by meristem tip culture and tip micrografting. In: HADID, A.; DHETARPAL, A.R.K.; KOGANEZAWA, H. (Ed.). Plant virus diseases control. St. Paul: American Phytopathological Society, 1998. p.436380 .

FAHY, G.M.; MACFARLANE, D.R.; ANGELL, C.A.; MERYMANN, H.T. Vitrification as an approach to cryopreservation. Cryobiology, San Diego, v.21, p.413-426, 1984.

FAJARDO, T.V.M.; BARROS, D.R.; NICKEL, O.; KUHN, G.B.; ZERBINI F.M. Expression of Grapevine leafroll-associated virus 3 Coat Protein Gene in Escherichia coli and Production of Polyclonal Antibodies. Fitopatologia Brasileira, Brasília, v.32, p.496-500, 2007.

FENG, C.; WANG, R.; LI, J.; WANG, B.; YIN, Z.; CUI, Z.; LI, B.; BI, W.; ZHANG, Z.; LI, M.; WANG, Q. Production of pathogen-free horticultural crops by cryotherapy of in vitro-grown shoot tips. In: LAMBARDI, M., et al. (Ed.). Protocols for micropropagation of selected economically-important horticultural plants. Methods in Molecular Biology, Clifton, v.994, p. 463-482, 2013. 
FENG, C.; YIN, Z.; MA, Y.; ZHANG, Z.; CHEN, L.; WANG, B.; LI, B.; HUANG, Y.; WANG, Q. Cryopreservation of sweetpotato (Ipomoea batatas) and its pathogen eradication by cryotherapy. Biotechnology Advances, New York, v.29, p.8493, 2011.

GAMBINO, G.; DI MATTEO, D.; GRIBAUDO, I. Elimination of Grapevine fanleaf virus from three Vitis vinifera cultivars by somatic embryogenesis. European Journal of Plant Pathology, Dordrecht, v.123, p.57-60, 2009.

GANINO, T.; SILVANINI, A.; BEGHÉ, D.; BENELLI, C.; LAMBARDI, M.; FABBRI, A. Anatomy and osmotic potential of Vitis rootstock shoot tips recalcitrant to cryopreservation. Biologia Plantarum, Dordrecht, v.56, p.78-82, 2012.

GARRIDO, L.R.; SÔNEGO, O.R.; GOMES, V.N. Fungos associados com o declínio e morte de videiras no Estado do Rio Grande do Sul. Fitopatologia Brasileira, Brasília, v.29, p.322-324, 2004.

GONZALEZ-ARNAO, M.T.; MARTINEZMONTERO, M.E.; CRUZ-CRUZ, C.A.; ENGELMANN, F. Advances in cryogenic techniques for the long-term preservation of plant biodiversity. In: AHUJA, M.R.; RAMAWAT, R.G. (Ed.). Biotechnology and biodiversity. Cham: Springer, 2014. p.129-170, 2014.

GONZÁlEZ-BENITO, M.E.; CLAVERORAMÍREZ, I.; LÓPES-ARANDA, M. Review: The use of cryopreservation for germplasm conservation of vegetatively propagated crops. Spanish Journal of Agricultural Research, Madrid, v.2, p.341-351, 2004.

GRIBAUDO, I.; CUOZZO, D.; GANBINO, G.; VALLANIA, R. Applicazione della tecnica di incapsulazione-vitrificazione per la crioconservazione e la crioterapia in vite. In: CONVEGNO NAZIONALE DI VITICOLTURA, 3 ., 2012, Firenze. Atti... Firenze: Italus Hortus, 2012. v.3, p.372-374.

HEE, S.J.; KYOON, K.D.; KEUN, S.J. Production of Yam mosaic virus (YMF-free Dioscorea opposita plants by cryotherapy by shoot-tips. Cryo-letters, Kew, v.34, p.149-157, 2013.
HELLIOT, B. Cryopreservation for the elimination of cucumber mosaic and banana streak viruses from banana (Musa spp.). Plant Cell Reports, Berlin, v.20, p.1117-1122, 2002.

MALIOGKA, V.I.; SKIADA, F.G.; ELEFTHERIOU, E.P.; KATIS, N.I. Elimination of a new ampelovirus (GLRaV-Pr) and Grapevine rupestris stem pitting associated virus (GRSPaV) from two Vitis vinifera cultivars combining in vitro thermotherapy with shoot tip culture. Scientia Horticulturae, Amsterdam, v.123, p.280-282, 2009.

MARKOVIC, Z.; CHATELET, P.; PREINER, D.; SYLVESTRE, I.; KONTIC, J.K.; ENGELMANN, F. Effect of shooting medium and source of material on grapevine (Vitis vinifera L.) shoot tip recovery after cryopreservation. Cryo-Letters, Kew, v.35, p.40-47, 2014.

MARKOVIC, Z.; CHATELET, P.; SYLVESTRE, I.; KONTIC, J.K.; ENGELMANN, FL Cryopreservation of grapevine (Vitis vinifera L.) in vitro shoot tips. Central European Journal of Biology, Warsaw, v.8, p.993-1000, 2013.

MATSUMOTO, T.; SAKAI, A. Cryopreservation of axillary shoot tips of in vitro-grown grape (Vitis) by a two-step vitrification protocol. Euphytica, Dordrecht, v.131, p.299-304, 2003.

MIAJA, M.L., GAMBINO, G., VALLANIA, R., GRIBAUDO, I. Cryopreservation of Vitis vinifera L. somatic embryos by vitrification or encapsulationdehydration. p.599-603. In: EUCARPIA SYMPOSIUM ON FRUIT BREEDING AND GENETICS, 11., 2004, Angers. Proceedings.... 2 v.

MURASHIGE, T.; SKOOG, F. A revised medium for rapid growth and bioassays with tobacco tissue cultures. Physiologia Plantarum, Copenhagen, v.15, p.473-497, 1962.

NISHIZAWA, S., SAKAI, A., AMANO, Y. AND MATSUZAWA, T. Cryopreservation of asparagus (Asparagus officinalis L.) embryogenic suspension cells and subsequent plant regeneration by vitrification. Plant Science, Limerick, v.91, p.67$73,1993$. 
NISHIZAWA, S.; SAKAI, A.; AMANO, Y.; MATSUZAWA, T. Cryopreservation of asparagus (Asparagus officinalis L. Osb.) embryogenic cells and subsequent plnt regeneration by a simple freezing method. Cryo-Letters, Kew, v.13, p.379-388, 1992.

PANATTONI, A.; LUVISI, A.; TRIOLO, E. Selective chemotherapy on Grapevine leafrollassociated virus-1 and -3 . Phytoparasitica, Bet Dagan, v.39, p.503-508, 2011.

PANIS B, PIETTE B, ANDRE E, VAN DEN HOUWE I, SWENNEN R Droplet vitrification: the first generic cryopreservation protocol for organized plant tissues? Acta Horticulturae, The Hague, v.908, p.157-162, 2009.

PANIS B, PIETTE B, SWENNEN R. Droplet vitrification of apical meristems: a cryopreservation protocol applicable to all Musaceae. Plant Science, Limerick, v.168, p.45-55, 2005.

PANIS, B.; PIETTE, B.; ANDRÉ, E.; VAN DEN HOUWE, I.; SWENNEN, R. Droplet vitrification: the first generic cryopreservation protocol for organized plant tissues? Acta Horticulturae, The Hague, v.908, p.157-163, 2011.

PATHIRANA, R.; CARRA, A.; MCLACHLAN, A.; HEDDERLEY, D.; PANIS, B.; CARIMI, F. Cryotherapy of grapevine (Vitis spp.) to remove leafroll viruses from infected plants. In: REUNIÃO BIENAL DA LINHAGEM, 20., 2013. Nova Zelândia. Anais... Wiaheke Island: Associação International de Biotecnologia Vegetal, 2013.

PATHIRANA， R.; MCLACHLAN，A.; HEDDERLEY, D.; CARRA, A.; CARIMI, F; PANIS, B. Removal of Leafroll Viruses from Infected Grapevine Plants by Droplet Vitrification. Acta Horticulture, The Hague, v.1083, p.491-498, 2015.

PATHIRANA, R; MACLACHAN,A.; HEDDERLEY, $K$. Cryotherapy: a new method for eradicating viruses from grapevine. New Zealand: Winegrower, 2012. p.77-79. Disponível em: $\leq \mathrm{http}: / /$ issuu.com/ ruralnewsgroup/docs/nzwg oct-nov $76>$.

PENNYCOOKE, J. C.; TOWILL, L. E. Medium alterations improve regrowth of sweet potato (Ipomea batatas L. Lam.) shoot cryopreserved by vitrification and encapsulation-dehydration. Cryo-Letters, Kew, v.22, p.381-389, 2001.
PLESSIS, P.C.; LEDDET, C.; DEREUDDRE, J. Resistance to dehydration and to freezing in liquid nitrogen of alginate coated shoot tips of grapevine (Vitis vinifera L. cv. Chardonnay). Comptes Rendus de I'Academie de Sciences, Paris, v.313, p.373-380, 1991.

SAKAI, A. Cryopreservation of germplasm of woody plants. In: BAJAJ, Y.P.S. (Ed.). Biotechnology in agriculture and forestry: cryopreservation of plant germplasm I, Heildelberg: Springer-Verlag, 1995. v.32, p.53-69

SAKAI, A.; ENGELMANN, F. Vitrification, encapsulation-vitrification and droplet-vitrification: a review. Cryo-Letters, Kew, v.28, p.151-172, 2007.

SAKAI, A.; KOBAYASH, S.; OIYAMA, I Cryopreservation of nucellar cells of navel orange (Citrus sinensis Osb. var. brasiliensis Tanaka) by vitrification. Plant Cell Reports, Berlin, v.9, p.3033, 1990.

SCHAFERMENUHR, A., SCHUMACHER, H.M., MIXWAGNER, G. Long-term storage of old potato varieties by cryoconservation of meristems in liquidnitrogen. Landbauforschung, Volkenrode, v.44, p.301-313, 1994.

SHATNAWI, M.; ANFOKA, G.; SHIBLI, R.; ALMAZRA'AWI, M.; SHAHROUR, W.; AREBIAT, A. Clonal propagation and cryogenic storage of virusfree grapevine (Vitis vinifera L.) via meristem culture. Turkish Journal of Agriculture \& Forestry, Ankara, v.35, p.173-184, 2011.

SIDRA - Sistema IBGE de Recuperação Automática. Produção Aagrícola municipal - quantidade produzida. Disponível em: $<$ http://www.sidra.ibge. gov.br/>. Acesso em: 20 abr. 2013.

SKIADA, F. G.; MALIOGKA, V.I.; KATIS, V.I.; ELEFTHERIOU, E. P.Elimination of Grapevine rupestris stem pitting-associated virus (GRSPaV) from two Vitis vinifera cultivars by in vitro chemotherapy. Eupopean Journal Plant Pathology, Dordrecht, v.135, p.407-414, 2013.

TORRES, A. C.; TEIXEIRA, S. L.; POZZER, L. Cultura de ápices caulinares e recuperação de plantas livres de vírus. In: TORRES, A.C.; CALDAS, L.S.; BUSO, J.A. Cultura de tecidos e transformação genética de plantas. Brasília: EMBRAPA/CNPH/ CBAB, 1998. v.1, p.133-145. 
VIEIRA, R. L. et al. Efficient elimination of virus complex from garlic (Allium sativum L.) by cryotherapy of shoot tips. Acta Physiologiae Plantarum, Berlin, v.37, p.1-11, 2015.

WANG, B.; WANG, R. R.; CUI, Z. H.; BI, W. L.; LI, J. W.; LI, B. Q.; OZUDOGRU, E. A.; VOLK, G. M.; WANG, Q. C. Potencial applications of cryogenic technologies to plant genetic improvement and pathogen eradication. Biotechnology Advances, New York, v.32, p.583-595, 2014.

WANG, B.; WANG, R. R.; CUI, Z. H.; BI, W. L.; LI, J. W.; LI, B. Q.; OZUDOGRU, E. A.; VOLK, G. M.; WANG, Q. C. Potencial applications of cryogenic technologies to plant genetic improvement and pathogen eradication. Biotechnology Advances, New York, v.32, p.583-595, 2014.

WANG, B.; YIN, Z.F.; FENG, C H.; SHI, X.; LI, Y.P.; WANG, Q.C. Cryopreservation of potato shoot tips. In: BENKEBLIA, N.; TENNANT, P. (Ed.). Potato I. Fruit, vegetable and cereal science and biotechnology. London: Global Science Book, 2008. v.2, p.46-53.

WANG, Q. C.; LI, P.; BATUMAN, O.; GAFNY, R.; MAWASSI, M. Effect of benzyladenine on recovery of cryopreserved shoot tips of grapevine and citrus cultured in vitro. Cryo-Letters, Kew, v.24, p.293302, 2003 b.

WANG, Q. C.; LIU, Y.; XIE, Y. H.; YOU, M. Cryotherapy of potato shoot tips for efficient elimination of Potato leaf roll virus (PLRV) and Potato virus $Y$ (PVY). Potato Research, Netherlands, v.49, p.119-129, 2006.

WANG, Q. C.; MAWASSI, M; LI, P.; GAFNY, R. ; SELA, I.; TANNE, E. Elimination of grapevine virus A (GVA) by cryopreservation of in vitro-grown shoot tips of Vitis vinifera L. Plant Science, Limerick, v.165, p.321-327, 2003a.

WANG, Q. C.; PANIS, B.; ENGELMANN, F.; LAMBARDI, M.; VALKONEN, J.P.T. Cryotherapy of shoot tips: a technique for pathogen eradication to produce healthy planting materials and prepare healthy plant genetic resources for cryopreservation. Annals of Applied Biology, Wellsborune, p.351363, 2009.
WANG, Q. C.; TANNE, E.; ARAV, A.; GAFNY, $\mathrm{R}$. Cryopreservation of in vitro-grown shoot tips of grapevine by encapsulation-dehydration. Plant Cell Tissue and Organ Culture, Dordrecht, v.63, p.41-46, 2000.

WANG, Q. C.; VALKONEN, J. P.T. Elimination of two synergistically interacting viruses from sweetpotato using shoot tip culture and cryotherapy. Journal of Virological Methods, Amsterdam, v.154, p.135-145, 2008a.

WANG, Q. C.; VALKONEN J. P.T.; Efficient elimination of sweet potato little leaf phytoplasma from sweetpotato by cryotherapy of shoot tips. Plant Pathology, Oxford, v.57, p.338-347, 2008b.

WANG, Q. C; VALKONEN, J. P.T. Cryotherapy of shoot tips: novel pathogen eradication method.

Trends in Plant Science, Kidlington, v.14, p.119122, 2009a.

WANG, Q. C; VALKONEN, J. P.T. Improved recovery of cryotherapy-treated shoot tips following thermotherapy of in vitro-grown stock shoots of raspberry (Rubus idaeus L.). Cryo-Letters, Kew, v.30, p.171-182, 2009 b.

YI, J. Y.; LEE, G. A.; JEONG, J. W.; LEE, S. Y.; LEE, Y. G. Elimination Potato Virus Y (PVY) and Potato Leaf Roll Virus (PLRV) Using Cryotherapy of in vitro grown Potato Shoot Tips. The Korean Journal of Crop Science, Suwon, v.59, p.498-504, 2014. 